$\mathrm{A} \int_{\text {ass }} \mathrm{H}$

Received : 04.09.2015

Revised : 28.10.2015

Accepted : 12.11.2015

RESEARCH PAPER

THE ASIAN JOURNALOF HORTICULTURE

Volume $10 \mid$ Issue 2 | December, 2015 | 232-236

Visit us -www.researchjournal.co.in

Members of the Research Forum Associated Authors: ${ }^{1}$ Department of Horticulture, B.A. College of Agriculture, Anand Agricultural University, ANAND (GUJARAT) INDIA
Author for correspondence :

N.V.SONI

Department of Genetics and Plant

Breeding, C.P. College of

Agriculture, Sardarkrushinaga

Dantiwada Agricultural University, SARDARKRUSHI NAGAR (GUJARAT)

INDIA

Email : soni1211@gmail.com

\section{Effect of planting density and integrated nutrient management on flowering, growth and yield of vegetable cowpea [Vigna unguiculata (L) Walp]}

\section{B.N. SATODIYA ${ }^{1}$, H.C. PATEL ${ }^{1}$ AND N.V. SONI}

ABSTRACT : A field experiment was conducted during the Kharif seasons of 2010, 2011 and 2012 to study the effect of planting density and integrated nutrients on flowering, growth and yield of vegetable cowpea cv. AVCP-1 at Horticultural Research Farm, AAU, Anand.The experiment was laid out in split plot design with three replications. From the three year data, it was found that plating density $60 \times 30 \mathrm{~cm}$ recorded the highest plant height however, it was comparable with $45 \times 45 \mathrm{~cm}$. Planting density $45 \times 45 \mathrm{~cm}$ recorded maximum pod weight and green pod yield which remained at par with planting density $60 \times 30 \mathrm{~cm}$. Whereas, planting density did not show any significant effect on days to flower initiation, days to 50 per cent flowering, number of branches per plant, pod length and number of seeds per pod. Application of nutrients $30+60+0 \mathrm{~kg} \mathrm{NPK} / \mathrm{ha}$ recorded significantly the earliest flowering. Application of fertilizer resulted in significant decreased in nodule production. However,any nutrients treatment did not observe the significant difference for days to 50 per cent flowering, plant height, number of branches per plant, yield attributing characters and green pod yield.

KEY WORDS : Cowpea, Nutrient management, Spacing, Split plot design

HOW TO CITE THIS ARTICLE : Satodiya, B.N., Patel, H.C. and Soni, N.V. (2015). Effect of planting density and integrated nutrient management on flowering, growth and yield of vegetable cowpea [Vigna unguiculata (L) Walp]. Asian J. Hort., 10(2) : 232-236. 